MANOUSOS KAMBOURIS

ANTONIS ALIADES

GEORGE HLIOPOULOS

SPYROS BAKAS

The Association of Historical Studies

KORYVANTES,

Athens, Greece

koryvanteshoplites@gmail.com
355.48(38)"362"

COBISS.SR-ID 219289612

Original research article

Received: September 21st 2015

Accepted: November 15th 2015

\title{
DRILL AND TACTICS OF EPAMEINONDAS'S THEBAN PHALANX IN THE SECOND BATTLE OF MANTINEIA 362 BC
}

\begin{abstract}
The tactics of Epaminondas in surprise, timing, and combined arms are still a subject of study. The direction of the Battle of Mantinea is considered his crowning achievement. Though, it is not universally accepted which exact formation he used, and few reside on how the whole maneuver was carried out from the point of drill and issuing battle orders. In this paper, a detailed account is proposed as to the exact drill applied by Epaminondas' Theban hoplites in the second battle of Mantinea, 362 BC. Taking account of the available drill level of the time, the detailed description of Xenophon and of similar allied and enemy tactics and intentions, we suggest that the Theban infantry line reformed from phalanx battle order almost to marching order under cover of dust and successful friendly screening action by light troops and cavalry. In this way, both directional flexibility and speed of movement was achieved so as to crash onto the enemy right, were the troops of value (by virtue or nativity) were always stationed by decree of tradition. After succeeding in their charge, Thebans lost cohesion and in the confusion, their general as well. Being irreplaceable, the victors stayed aghast allowing the enemy a counterattack which snatched a draw from the jaws of defeat. This string of events is indicative of an elaborate and extra privy plan, demanding the presence of the mastermind proper to fulfill it. The only possible intent, which was risky, sensitive and decisive, is for Epaminondas to intend to reform his phalanx line perpendicularly to the enemy's already smashed one. This plan imitates standard Spartan flanking intentions without the need of the extreme Spartan maneuvering ability and indicates that the most suitable attack formation had been at this case to revert to marching order. Thus redeployment was easy, contrary to the generally assumed addition of fully deployed units in successive lines to achieve the desired depth with less effort. Such theories and conclusions may be bolstered only by experimental archeology and living history approaches, as dynamic concepts may be proved or disproved only by experiment, this study does not constitute proof. But entails a definitive positive value; if a concept is workable today, it has always been so, although the actuality is far from definitive.
\end{abstract}

\section{KEYWORDS: HOPLITE, PHALANX, DRILL, EPAMEINONDAS, MANEUVERING.}

\section{INTRODUCTION}

The phalanx of Epameinondas, especially at its more mature use in Matineia $362 \mathrm{BC}$, is the subject of intense speculation. For a second time, the Theban general manipulates his troops and the enemy so as to crash his opponent by charging with a very deep formation at the enemy right, where the best troops traditionally stand. After 
one such success at Leuctra, in $371 \mathrm{BC}$, where the enemy was surprised by the first application of this tactic, one would expect that the Spartan professionalism would have devised countermeasures, as the Theban practice was extremely risky and time-sensitive: its execution offered a window of opportunity to the enemy to implement a flanking move-a Spartan specialty-and obliterate expeditiously and totally the charging column. Of course, generalship is expecting, foreseeing and countering; though, it is intriguing to understand how this master plan was implemented on the field. The challenge lies in finding a way which can ensure the prompt formation of the assault column, allow very fast closing with thev enemy without loss of order or cohesion, provide for follow-on after the breaching of the enemy line and combine with other arms so as to shirk anyexposure to superior Spartan maneuverability or steadfastness when similar numbers are engaged.

The surviving description of the battle is owed to "Hellenica" of Xenophon, a meticulous writer and expert in describing matters of tactics and technique as befits a seasoned warrior and author of training and tactical manuals. Xenophon is a staunch supporter of the extended, thin lines which allow flanking moves as orders the Spartan dogma (Kyropaedeia), and, of course, of the vigorous training and cohesion needed to instill solidarity to thin-lined phalanxes and drill to allow them to maneuver with tactical effect. From his description, compared and completed with elements of other works of his, as a contemporary to the events and a fellow soldier, we must extrapolate to understand the exact string of events.

To employ a tactical innovation, one needs a suitable tool. The Theban army of Epaminondas has two important characteristics allowing it such grading: First, it trains regularly and intensely (Plutarch Moralia 71.18), as no other civilian army has done during Xenophon's time-except the quasi-professional Spartan army (LP XI,8). Thus his men possess stamina, endurance, cohesion and discipline. The Theban (or, rather, the
Boetian) army is not as sharp an instrument as the notorious red cloaks, but it is much bigger, can make up losses, integrate new allies fast and use them to good effect, perhaps after a retraining scheme (Hellenica VII.5.19). Second, it creates its myth and lore. Epaminondas insists in continuous training and separate encampment to create an air of superiority, mystique and curiosity (Plutarch, Moralia). It is very much an army antispartan of purpose but made of the same ingredients, only with stronger, heavier and numerically more troopers (Diodorus XV.87.1)- instead of the Laconian lean and mean and invaluable few.

\section{LITERARY EVIDENCE, EXTRAPOLATIONANDARGUMENT}

\section{Facts, variables and correction factors \\ Biases and the standard level}

First, Xenophon by definition despises Epaminondas, but cannot afford, as a genuine aristocrat, to slander or openly denigrate him. As a historian he is as objective as could be hoped for. His writing is colored but true. Thus, it is of the outmost importance to compare his narrative with more technical knowledge, especially if provided by him in his other works (Anabasis, Lakedaimonion Politeia -State of Lakedaimonians, Cavalry Commander - Hipparchikos, On Horsemanship - Peri Hippikis, Kyropaedeia).

The focal point in explaining tactics is drill and mobility. Both are well attested for the Spartans, the undisputed tactical masters of hoplite warfare for 200 years. They were reluctant to send expeditions far at the time of Xenophon (to be understood as "expeditions manned with Spartan Equals"), but had a long history of even overseas interventions during the 6th and 5th centuries (Lydia, Samos, Attica, Aegina) with task forces containing Equals (Herodotus I.83 III.54; V.63-4; VI.73). Moreover, they were very well 
acquainted with such endeavors, as both Herodotus in $479 \mathrm{BC}$ at the Plataea campaign and Xenophon at Lakedaimonion Politeia attest (XI.2). They can be very fast in strategic maneuvering; in 490 they surprise everyone when coming to the aid of Athenians in less than 3 days (Herodotus VI.120), in Thermopylae $480 \mathrm{BC}$ they arrive at the nick of time to raze the Malian fields for Xerxes to find no supplies and just before Plataea, in $479 \mathrm{BC}$, their progress takes by surprise (Herodotus IX.11-12) friend and enemy alike (Athenians and Argives, respectively). But they move to fight; they do not fight by moving. Xenophon attests that Jason of Pherrae was the first general to do so (Hellenica VI.4.21), recognizing both a strategic and operational dimension in mobility. Is he ignoring Epaminondas? Perhaps he is a bit off the mark: Persian armies were doing so centuries ago, and some of Epaminondas operations might be regarded under such a light. There are some opposite thoughts, though: the invasion of Laconia by multiple routes is nothing different than the three-pronged advance of Xerxes between Thrace and Macedon (Herodotus VII.121) or the Athenian disastrous attack in Boeotia in 424 BC (Thucydides IV.89). The maneuvering culminating in the great battle of Mantineia in $362 \mathrm{BC}$ (Hellenica VII.5.9-15) is something more than the Athenian and Persian competitive operational maneuvering before, during and after Marathon in $490 \mathrm{BC}$ (Herodotus VI.102-3 and 115-8 respectively) but nothing different. After all, Xenophon is an expert on the subject: he serves for years as a condottiere near the greatest general of the old, moving-tofight concept, Agesilaos of Sparta. And he does not see the mobility of the Theban army as of any consequence.

The issue in Mantinea $362 \mathrm{BC}$ is clearly the drill, since mobility played no important role in the clash of phalanxes. Xenophon describes drill as a Spartan exclusivity with the other Greeks stubbornly ignorant (LP XI.4/8); though, one may accept an unorganized motion from camp to battle line in some cases, especially in more formal and restricted battles, but cases -as is Marathon 490 BC- cannot be explained without taking proper drill as a fact. Thus, the Deployment (paragogi) is the only logical way to transform a column of march to a battle line (LP XI.9) and it is very weird how all the expediting Greek armies could do so without implementing paragogi, according to Xenophon. Moreover, the countermarch (exeligmos-ibid) is the only drill satisfying the Occam's razor for the battle of Marathon. So, given that some of his drill information is incomplete, incoherent and irrational, it is logical to suspect deliberate self-restriction in making the Lakonian secrets known in detail. Consequently, should we assume some margin in this particular point? For example, after attesting the countermarch to reverse the front of a deployed phalanx, he mentions that in a similar way the Spartans achieve the exchange of its flanks (LP XI.9). This is problematic: if a man's front is half a meter and the usual file depth of the Spartans is 12, as in Leuctra (371 BC) for a 3600-strong Spartan phalanx (6 Morai of 600 men each-LP. XI.4) the front is 150 meters. The standard countermarch (Lakonian or Macedonian) was less than 15 meters and considered a feat of drill, training and discipline!!!!

\section{The paradigm-shifter: the new Theban army}

To resolve the issue in Mantineia, we must understand the formation of the Theban-allied army and determine its structure and potential; only in this way the string of events will be elucidated-and the just as important string of intentions. If focused on phalanx, this is impossible. Thebans must have retained the bronze-age 50 men basic heavy infantry unit (Iliad IV-393) and the Taxis brigade used in Athens (Hellenica IV.3) and by almost all other Greek army but the Spartan (L. P. XI.4). The Taxis is 1000 strong, give or take. The Theban heavy infantry where hoplites, but did not fight any more as a classical phalanx in mechanics and tactics; only as a technique. Instead of lim- 
iting themselves to spear stabbing (doratismos) and shield shoving (othismos), they reverted at Epaminondas instigation to grappling at contact, were well-trained in individual combat, open to the thrill of the initiative to the point of individualism or even undisciplined, kept no dressing of the lines, rushed at the opponent in deep formations reminiscent of Homeric "towers" (perhaps similar to French columns). Such is the picture compiled by both Xenophon and Plutarch, who hold opposite views and are almost a millennium distant. Although instructors of close combat (oplomachoi) were supposedly denied access in Spartan territory, they were sought for in Athens and there is no reason to think differently of Thebes. Proficiency in Close Quarter Combat was important when phalanxes have clashed and one is broken, and the other in hot pursuit, thus losing its integrity. The Spartans did no such things. They did not break, to be pursued, and themselves pursued for a short distance as an unbroken phalanx, to null any individual advantage to adversaries. They were not out for mass murder, but for victory with as little loss of invaluable Laconian warriors as possible.

Given that the Theban novelty is to strike with great depth and fast at the enemy strong contingent, to the right, to break the phalanx and decapitate the enemy, gaining a decisive and immediate victory, as happens in both Leuctra and Mantineia, the outcome in both cases is questionable. After Leuctra the Thebans ask for reinforcements from Alexander of Pherrai to wipe out the remaining Spartans, despite the astounding victory in both psychology and body count. After Mantinea, they are advised by the victor, dying Epaminondas to sue for peace. Their victories are decisive but not total. The smashing of the opposing phalanx in a very limited front cannot disintegrate it, especially if it is big and filled with purpose (as in Mantineia but not in Leuctra). The deep formation and the irresistible charge, combining (unexplainingly) othismos and Pankrateion is instrumental, but it is only part of the picture. Xenophon describes meticulously that in Mantineia the Thebans screened successfully their phalanx transformation behind a screen of cavalry and light troops who bested their opposite numbers. Thus, the deployed phalanx reformed, by bringing more lochoi behind the front ones and acquiring great depth. There is a problem as to the size of lochos; in Xenophon's March of the 10,000 they are specifically mentioned as 50 and 100-strong, perhaps depending on the contingent. It is definitely the lower echelon of the Taxis in both Attic and Theban armies, as the Theban Sacred Band is 300 strong -but it cannot be considered a proper lochos due to the sacramental nature of the unit. Though, the 50-strong lochos fits nicely to the testimony of Theban phalanxes 25 and 50 deep (Delion 424 BC -Thucydides IV.93- and Leuctra 371 BC-Hellenica VI.4.12). If the Theban field lochoi are 50-strong, whole lochoi were deployed in just two or one file(s) respectively at the aforementioned battles.

This deployment of lochoi in very few, very deep files is nothing weird; it is similar to the order of march-only denser- and gives a deep formation, irresistible in shock action and fleet in charge, as it needs no dressing. It is also easy to manipulate in lateral direction in the battlefield so as to deploy the phalanx as needed, the deployment, though, is slow and presents the worst window of vulnerability. This deficiency and the exposed flanks are the reason nobody used it. But Epaminondas used proficiently his superior cavalry and light infantry, not to decide the issue (as a Spartan would have done, see Gylippos in Syracuse, 413 BC- Thucydides VII.6) but to allow its heavy infantry to decide the issue in a much more decisive way: a hoplite victory would crash enemy morale and incur horrific casualties as the shock would be by armored men striking in contact. This whole idea reminds of Napoleonic attack columns of the French infantry and to be implemented it is imperative to accept that the Theban army of Epaminondas possessed, among others, the drill level described by Xenophon as Spartan only. 


\section{Possible Vs available drill and maneuvering}

The easy approach

Up to know it is intuitively assumed that the deployed Theban phalanx started its advance under cover of dust at the left. The leftmost phalanx-deployed Lochos having advanced 10-15 meters, the next at its right would have perform a half-turn left by each man, advance at its rear, half-turn right to regain its front and start advancing at the tail of the preceding one; this continues for the whole Theban contingent, creating a very deep formation at the width of one Lochos (Figure 1). It is simple enough and entirely doable, while retaining a very narrow front, just six men had the Theban Lochoi deployed to a file-depth of 8 men, as was normal for other Greek armies (as the Athenian). This would mean that in Delion three Theban Lochoi would line ahead and in Leuctra 6, while the arrangement is similar to the Persian in Plataea (Herodotus IX.31.1), whence the Thebans were the staunchest of the Persians'allies.

But it fails to fully comply with Xenophon's account in many respects, and it offers no real advantage in the collision match of othismos, as a normal lochos assaults the enemy and the amassment of more such lochoi in depth might have been of limited practical use at the shoving. The most important problem, though, is that after shattering the enemy, this formation can do little if the rest of the opposite phalanx does not turn and flee (Figure 2). Actually, if the units near the impact turn to the breach and charge from the side, it is very probable that the attacking column will be disintegrated, if hit at the shieldless side. The Thebans knew that the secret to obliterate an enemy army is to flank it and advance perpendicularly to its axis of advance, as the Spartans had done in Mantinea in 418 BC (Thucidydes V.73) and in Nemea, in 394 BC (where assaulted in such a, lateral charge, a rather decently-faring deeply deployed Boetian contingent of the enemy phalanxHellenica IV.3).

\section{The factual approach}

The alternative, as proposed herein, is the assumption that the recent level of Theban drill and confidence allowed something much more complicated, which would pay up with a much more decisive result. In this account, the Theban left, under cover of dust from the cavalry screen, transforms starting at the extreme left from phalanx line to column (epagogi-Figure 3), with increased depth and much narrowed front; possibly its front line is made exclusively of Lochos commanders (Lochagos), as their commands-Lochoi- are formed behind them in single file each. Next (rightward) lochoi followed suit and perhaps a second level of such lochoi might have been formed (Figure 4). The Theban formation becomes thus very deep, and the first line is composed by picked men, Lochoi commanders. Moreover in a very deep lochos, its members (lochitai) have better cohesion and might bring more weight to bear than the same number of men from successive lochoi. This extreme depth would much more fit the description of the Theban attack as a trireme ramming the side of the enemy, proposed by Xenophon (Hellenica VII.5.23) and cope with the crack Spartan first line from an advantageous position (Figure 5).

The most important issue is, though, what happened and what was going to happen next. After beating the enemy phalanx and rupturing it, Epaminondas was shot by a Lakedaimonian javelineer, a peltast, while he was ready to move on to the exploitation of the successful clash. With his loss, the Thebans could not capitalize on the initial-and, agreeably, decisive-success (Hellenica VII.5.25). As Xenophon says, the Athenians were victorious against the allied contingent of the right flank (ibid) and both contestants disengaged in good order with both ritually claiming victory and neither being confident to challenge the other's claim of victory (Hellenica VII.5.27). This version is Xenophon's, though the political history from then on shows that he is right. The second 

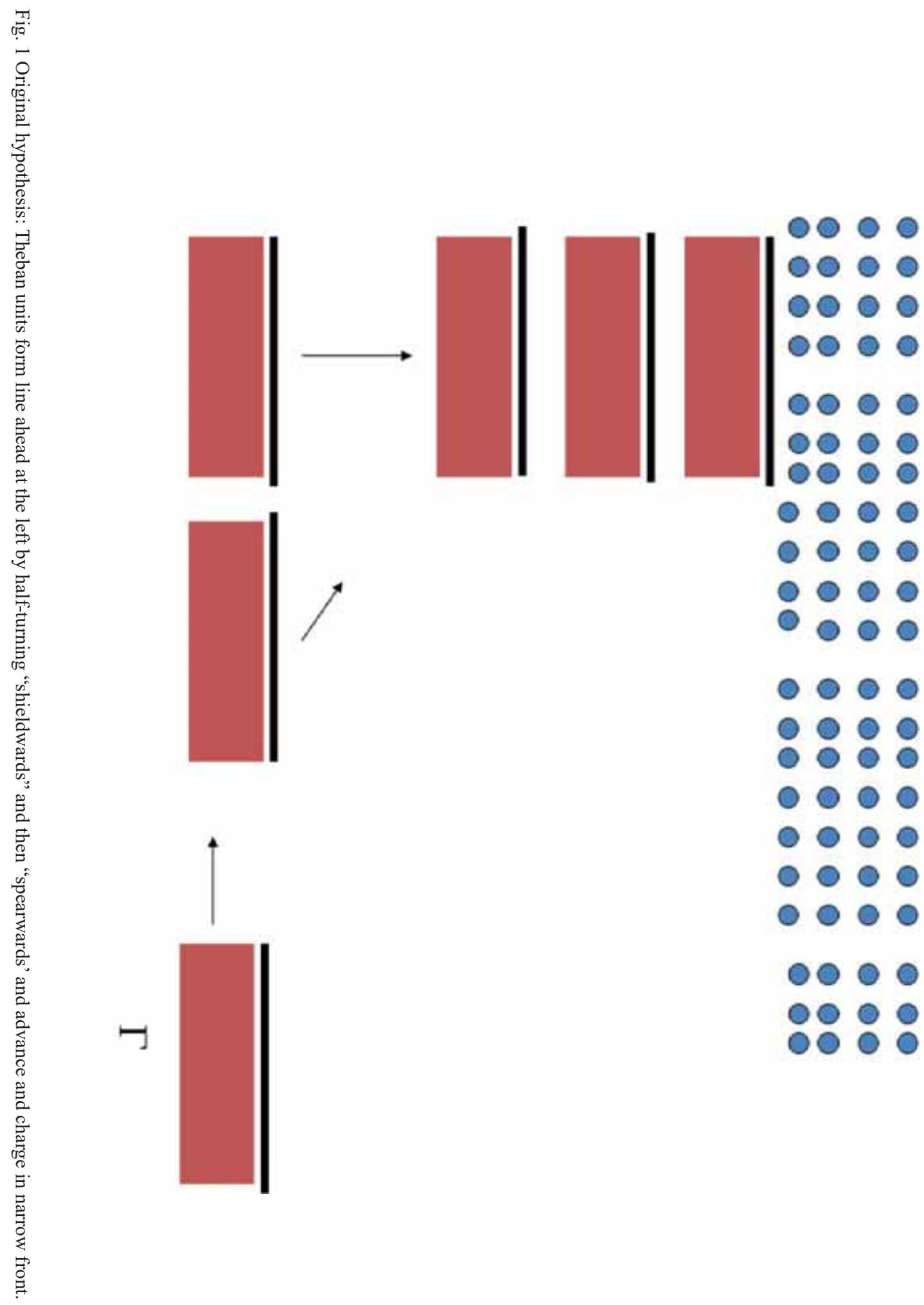

$\circ \circ \bigcirc$

- 00

- 000

- 00

- $0 \circ$

- -0

- 00

- 00

- -0

- 00

- 00

○○ 0

900 
daughter of Epaminondas, the victory at Mantinea (Diodorus XV.87.6) was a half-blood child.

This realization shows the conventional wisdom of traditional Greek practice (as in Platea in 479 BC-Herodotus IX.27.6) to deploy at the left end their second best troops (the cream at the right), compared to Epaminondas' practice, to deny one of his flanks by keeping it lagging. One cannot bet on this being a stroke of luck for the antitheban side as the battle was unfolding, or some good Athenian tactician (there were 2 or 3 at this time) having understood his opponent's methods and devised suitable countermeasures. But the most important thing is to realize that the Thebans had not fulfilled their intention for full exploitation of victory, which was a standard operating procedure. It is impossible not to have a plan so as to disintegrate the enemy before the vulnerable, lagging flank becomes engaged by superior enemy forces. The whole idea was a run against the clock, as was performed brilliantly by the Spartan army in the battle of Nemea, in 394 BC. At this battle the Spartan right broke and disintegrated the enemy left and redeployed at right angle to the original front, advancing at the enemy flank which had been victoriously sweeping the field. Thus, if the Thebans were planning something similar, they needed redeployment. It is very tempting to suppose that after annihilating the Mantineans and Spartans, the Thebans were redeploying (paragogi-LP XI.6) into phalanx to take the rest of the enemy phalanx at the internal flank created by the frontal rupture of the extreme right (Figures 6-7) as had been the case in Tegyra in 377 BC. But in Mandinea the massive deployments dictated drill and discipline instead of brilliant improvisation by the elite professional troops of a very cohesive, permanent unit which had been enough for the small number engaged in Tegyra. At this point, Epaminondas, being with his men at the spearhead of the attack, was exposed and hit by the Lakonian light trooper who was there to cover the retreat of his beaten compatriots. By being wounded and incapacitated, Ep- aminondas was not able to give the orders for the redeployment and the Thebans did not exterminate the enemy phalanx in time; due to this, their own was badly mauled by the untouched enemy left (Athenians) and they themselves exposed and compromised. Without Epaminondas they were not so much equals to the redcloaks.

\section{CONCLUSION}

We conclude the key issue has been the lateral advance, which the Thebans were planning to execute by creating an internal exposed flank to the enemy, as they did not possess the maneuvering proficiency shown by the Spartans at the First battle of Mantineia in 418 BC (where they outflanked their opposing phalanx); on the other hand, the Thebans brought superior brute force to bear. If this simple fact is taken into account, all fall into place. The trireme-like assault, like the French charge columns, was supposed to crash with the best Theban troops into the enemy phalanx at a very limited width, and next, being driven into it to deploy perpendicularly to the enemy phalanx as it would have been placed squarely at its flank. The charge would sweep the enemy, who could not move fast enough to flank the Thebans or to get out of their way-but by reverting to outright rout. To perform all these, the Theban phalanx, deployed against the enemy one for some time, must have transformed under cover of dust to form its basic units into single-file extra deep, marching formation, but arranged both one next and one after the other. The best troops would all have been at the first line to crash on the enemy phalanx with the momentum of a running charge and of an extraordinary depth.

The only problem is the questionable ability of Thebans to execute such drill, a traditional privilege of the Spartans and their Agoge public training system. But this idea of Spartan monopoly might be exaggerated, as it originates from Xenophon have been. There are no contrary assertions, 


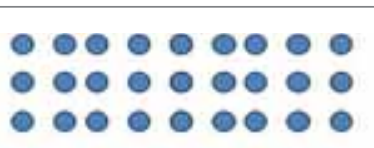

A

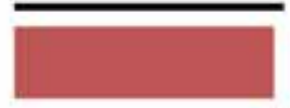

B

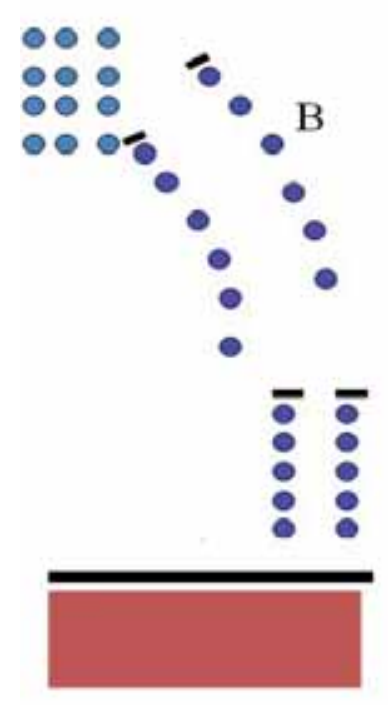

$\Gamma$

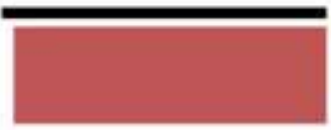

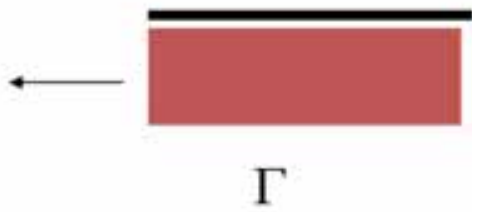

Fig. 2 Original Hypothesis: The following Theban units turn right and left to flank-attack the exposed units after the top of the column has broken through and is in hot pursuit of its immediate antagonists.
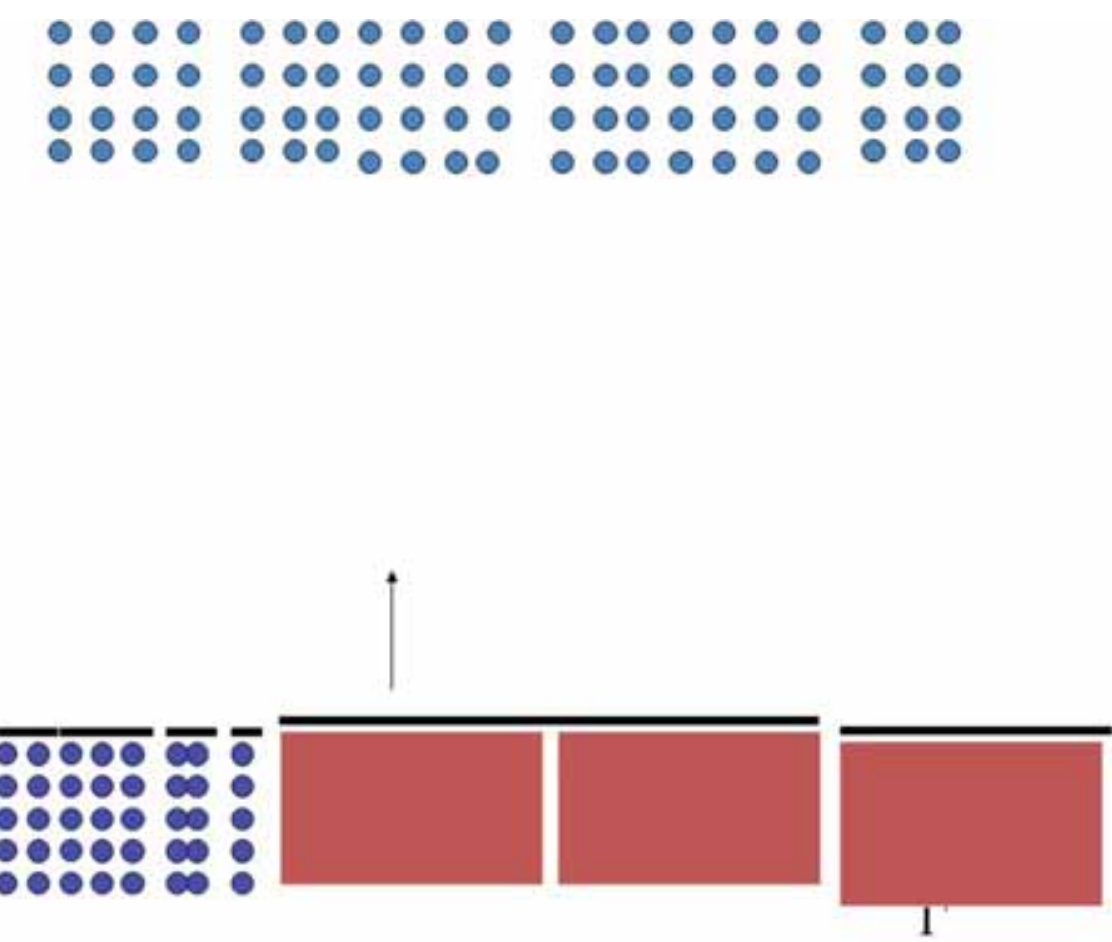

Fig. 3 Projected hypothesis: The Theban units transform from line to column bydiminishing the file number and increasing the file depth while maintaining the same linear density, thus shrinking the front. 

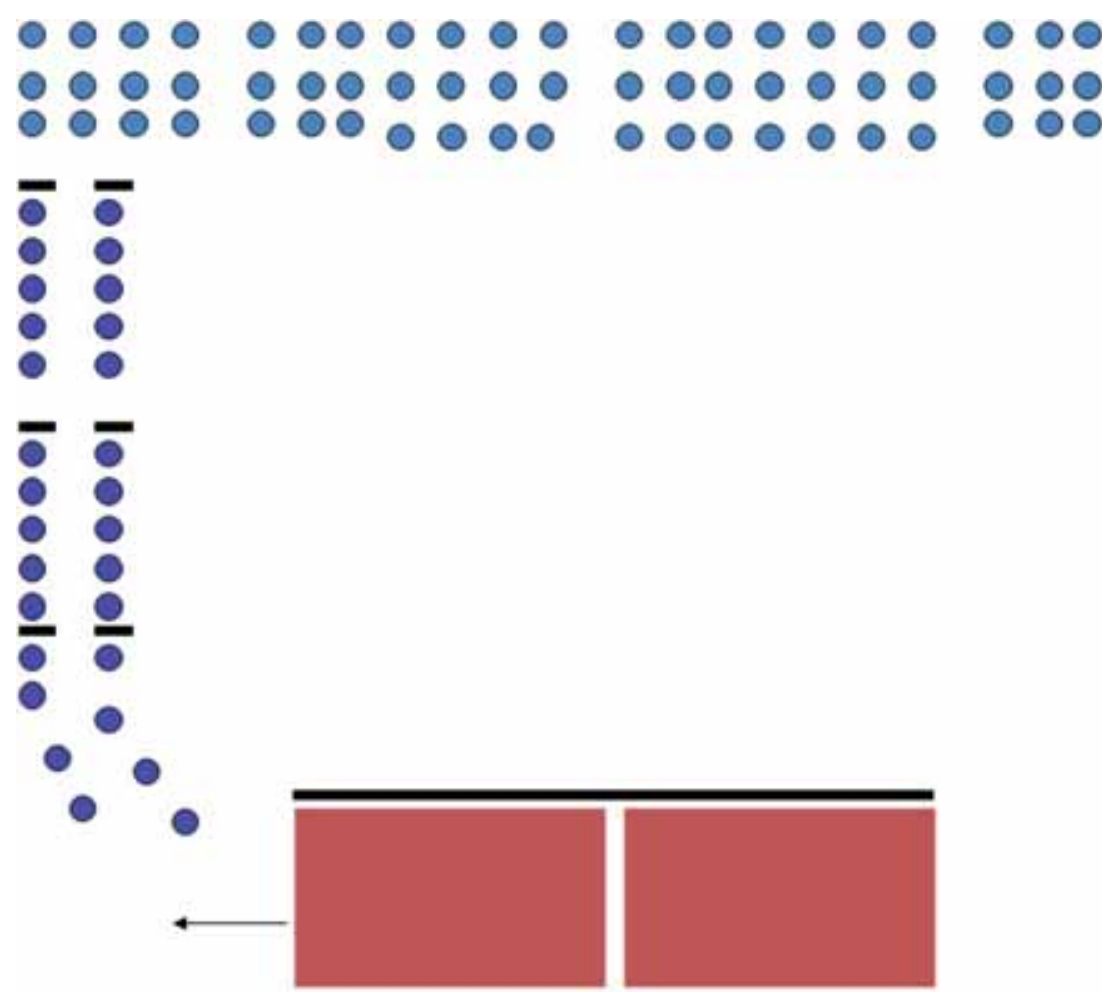

Fig. 4 Successive units move leftwards (shieldwards) by transforming in succession

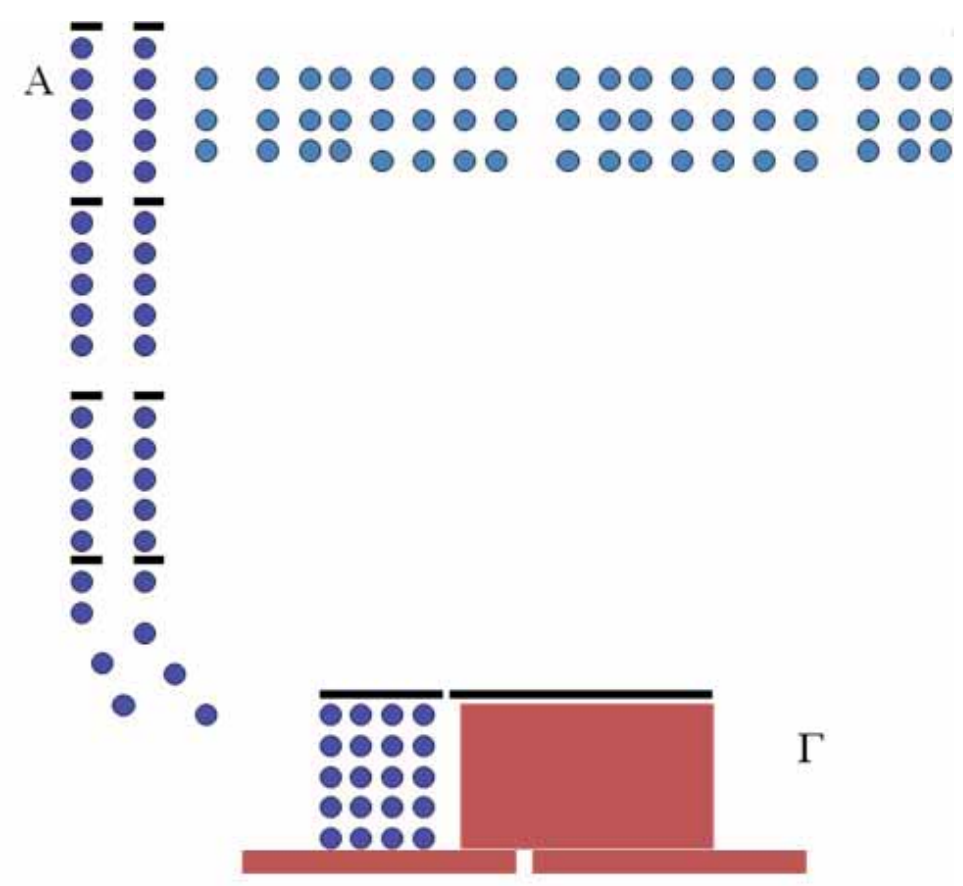

Fig. 5 The narrow front of the Thebans breaches enemy phalanx as a napoleonian assault column. At this point Epameinondas is slain 


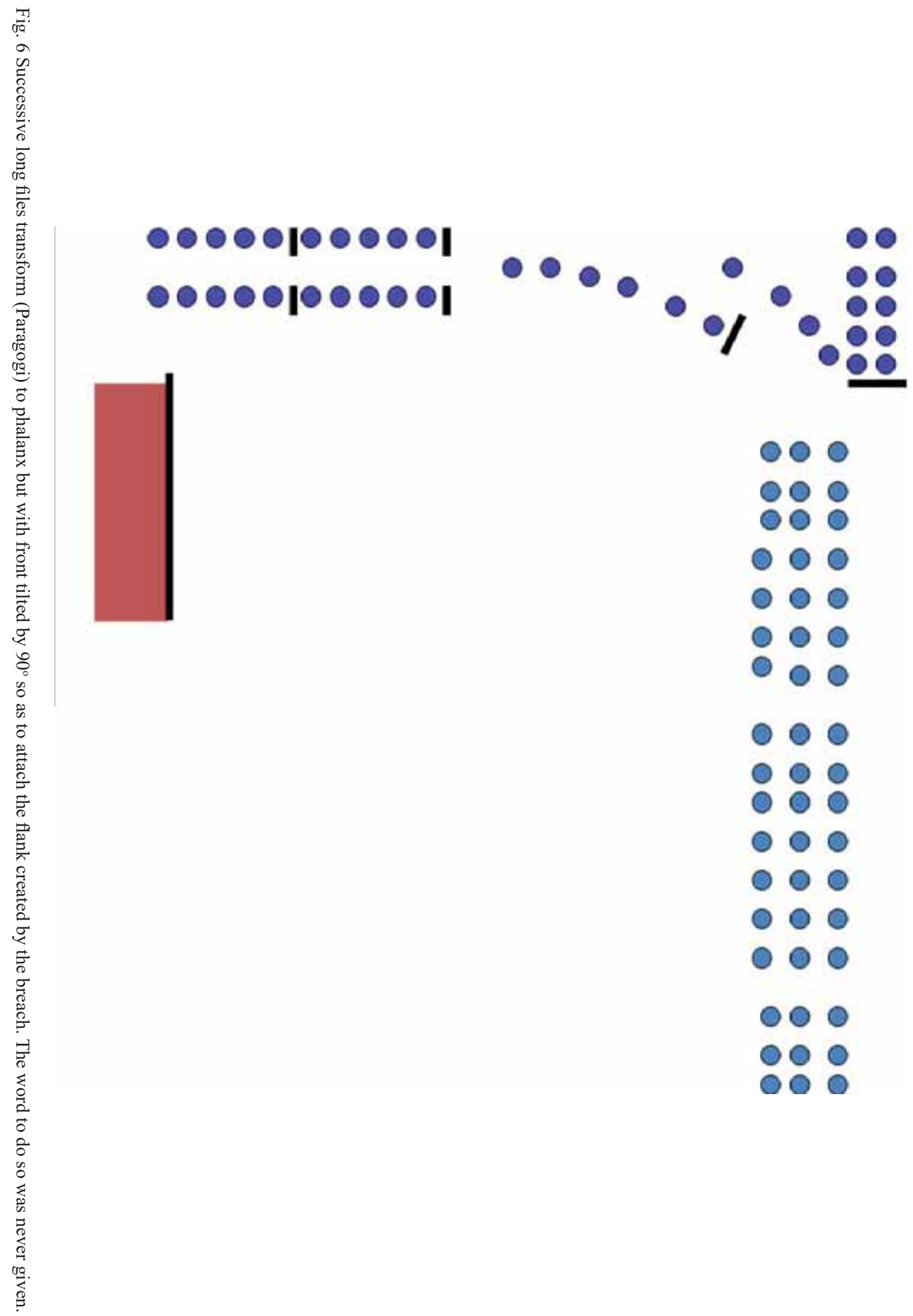




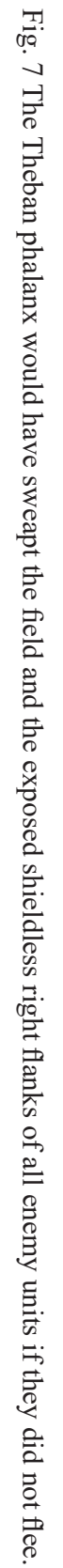
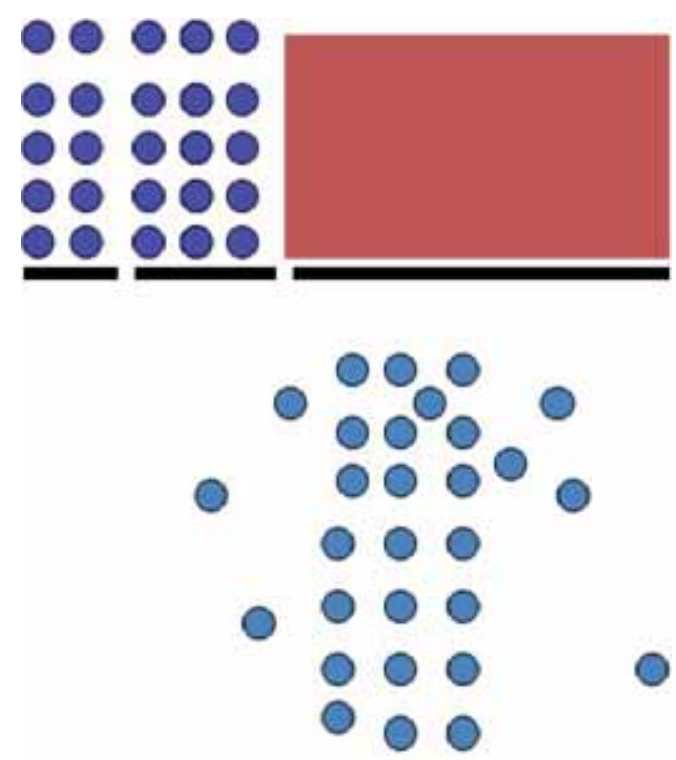

000

$\circ \bigcirc$

000

000

000

000

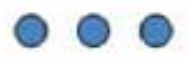

000

100

000 
but some strong indications that this level of drill cannot have been Spartan monopoly. In any case, the assumptions presented need a robust plan of reenactment and experimental archeology. The prompt raising of weapons, the transformation on the move and the collision mechanics might back up one of the two transformation alternatives and prove or disprove the idea of the lateral advance on the internal flanks created by the clash and the way the change of front by $90^{\circ}$ was achieved in limited time and space. If proven, this might change our view in how Spartans turned in Mantinea and Nemea and perhaps even the about-turn of the Athenian wings in Marathon.

\section{BIBLIOGRAPHY}

Homer, The Iliad

Herodotus

Thucydides

Xenophon,Hellenica

Xenophon, Lakedaimonion Politeia

Xenophon, Kyropaedeia

Diodorus Sicilus

Plutarch, Moralia

\section{REZIME \\ PRODOR I TAKTIKA \\ EPAMINONDOVE TEBANSKE FALANGE U DRUGOJ BITCI KOD KOD MANTINEJE 362 GODINE STARE AERE}

KLJUČNE REČI: HOPLITI, FALANGE, PRO-
DOR, EPAMINOND, MANEVRISANJE.

Epaminondova taktika koja se sastojala $\mathrm{u}$ iznenađenju, vremenu, kao i kombinaciji oružja još uvek predstavlja predmet istraživanja istoričara. Bitka kod Mantineje se smatra njegovim vrhunskim dostignućem, iako nije opšte prihaćena formacija koju je on koristio u ovoj bici. U studiji smo pokušali da detaljnije osvetlimo tok prodora koji su primenili Epaminondovi tebanski hopliti u drugoj bici kod Mantineje 362. godine stare ere.

Uzimajući u obzir raspoložive podatke o prodoru, kao i detaljan opis Ksenofonta pokušali smo da predložimo moguću verziju ove velike bitke.

Teorijska postavka u vezi taktike $\mathrm{i}$ ishoda bitke mogu se donekle potvrditi ili opovrgnuti samo eksperimentalnom arheologijom. To svakako ne predstavlja dokaz, ali podrazumeva pozitivnu vrednost, iako je odgovor još daleko od definitivnog. 